\title{
Comparing Two Latin Poetic Dedications by Anthony Munday and Robert Greene ${ }^{1}$
}

\author{
W. Ron Hess
}

\begin{abstract}
This article compares two Latin poem dedications which may contain hidden sub-meanings and possible displays of a basic puzzle method called acrostics, each dedicated to the same nobleman. The Latin verse in 1579 by Anthony Munday follows acrostic English poems and may refer to his patron as “a lover of Pallas Athena” (the Spear-shaker of Greek mythology). The Latin verse in Robert Greene's 1584 book may contain a Latin acrostic and appears to identify Cupid, the "winged Love," as a companion of the same patron as Munday's from five years earlier. That Cupid trope appears similar to "the little love god" allusions to Cupid in several of Shakespeare's sonnets (e.g., \#s 153 and 154). More than these discussions, this article explores difficulties of translating from Latin into English, or vice versa, and the pitfalls which can occur.
\end{abstract}

Keywords: Latin Translations; Anthony Munday; Robert Greene; Edward DeVere, 17th Earl of Oxford; Shakespeare's Sonnets

\section{Introduction}

In the front matter of 1579 Mirrour of Mutabilitie, his first-ever published work, Anthony Munday dedicated the book in English to Edward DeVere, 17th Earl of Oxford, even featuring Oxford's name and titles "hidden" in several acrostic poems (see Figure 1 for the first acrostic). An acrositic poem was a cute puzzle wherein, reading down the left margin, the capitalized first letter of each line spelled out a not-so-hidden message. Indeed, many of Munday's poems in that volume were acrostic, spelling out the evils that caused the downfalls of the tragic subjects of Mirrour (such as King Herod's “WRATHE”). Normally the intent of an acrostic was that it may be easily discovered and yet present an easily interpreted, coherent message. ${ }^{2}$ Then, some four pages from the end of the book, written in Latin, Munday included an unsigned further dedication to Oxford which has not

W. Ron Hess, Retired Professor in IT Security and Federal Civil Servant; e-mail: BEORNsHall@earthlink.net; website: http://home.earthlink.net/ beornshall/index.html/.

1 This article is an update to and correction of the article \#10 posted by the author on his website (http://home.earthlink.net/ beornshall/index.html/). In particular, this update features translations and opinions by Prof. Dana F. Sutton which are more accurate than those used in article \# 10.

2 Probably the most famous acrostic of more modern times was the poem by Charles Lutwidge Dodgson (alias "Lewis Carroll”) at the end of his 1871 Through the Looking Glass, in which he featured an acrostic on "Alice Pleasance Liddell," thus revealing the name of the girl who inspired his 1865 Alice's Adventures in Wonderland. Ironically, Dodgson's alias was derived via Latin translation of his first two names into "Carolus Ludovicus" and then reversing and retranslating them into English (see Encyclopedia Brittanica 1986 ed., Vol. 2, p. 902). 
been much noted by scholars. Munday’s Latin poem (see Figure 2) seemed to be a wistful paean to a tired traveler after a perilous mission abroad, which it so happens fitted both Oxford in 1575-76 and Munday in 1578-79, after each had returned from wide travels to Italy. Except that whereas Munday’s travels only crossed the sea at the Channel, the Latin poem focused on a tiring sea voyage, such as Oxford had in Italy and Greece in the summer of 1575; and in terms of the risks alluded to in the poem, Oxford's return crossing of the Channel in 1576 had him taken by Dutch pirates and his life briefly put in jeopardy (Nelson, 2003, pp. 137, 141). On translation into English, the 1579 poem by Munday remains opaque_-appearing to hint at deeper things_-but isn’t that what all good poetry does? And, heightening the mystery, the enigmatic Earl of Oxford, to whom the book and Latin poem were addressed, was shortly afterward a noted poet-playwright himself (Ibid, pp. 385-387, noting praises of Oxford by critics Wm. Webbe 1586, Geo. Puttenham 1589, and Francis Meres 1598).

\section{T $\mathrm{T}$ be $\mathcal{A}$ uthors Commendation of the laigbt tonotable carle of \\ Oxentord.}

E rcept $\dot{3}$ thoulo in frénothip féme irgrate,

D enving outp, where to 3 am bouno:

W itb letting aip your bonno2s vowetbe ftate,

A tall alfayes, wbich 3 baue $\mathbf{p o b l c}$ founo.

$R$ igbt loell 3 migbt refrapuc to banole pen:

D enouncing age tbe companz of men.

D olon oire ocfpapec, let courage come in place,

E ralt bis fantc whoin bisonno; owtb tmbace.

$V$ ertue batb ape aoonno pour valiant bart,

E ramipleo by pour oxos of lafting fame:

R egaroing fucly as take $\mathcal{O}_{00}$ Mars bis parte,

E rbe wbere be pzofe, in lyonnoz and in name.

E the onc ooth knowe no fables $X$ erpaette,

A s though 3 itjoulo encrocbe for patuate gapne:

R egaro pou map (at pleafure) 3 confetfe;

$\mathbf{L}$ etting that parti, $\mathbf{z}$ voucb to o3cao no paine.

$\mathrm{E}$ cbe wberc, gaint fuch as can my faitb oiffaine.

$\mathrm{O}_{2}$ once can (ap, be veales Lith tatterye:

F owging t, is ta cs to pleafe tbe fantafyc.

O f mine intent prour bonmo? iubge 3 crauc,

$\mathbf{X}$ ephirusblolvi rour ffame to gibient flipes:

E rtoll 3 pzap tljis baliant Brittayne batue,

$\mathbf{N}$ of femting once Bellona to ocfpife.

F 02 Galliantnes beboloe voung $\mathrm{Crefarbáre,}$

O 2 Hanniball loe Heriules in place:

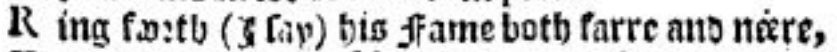

$\mathrm{D}$ out not to fap, De Vcre will focs osface. 


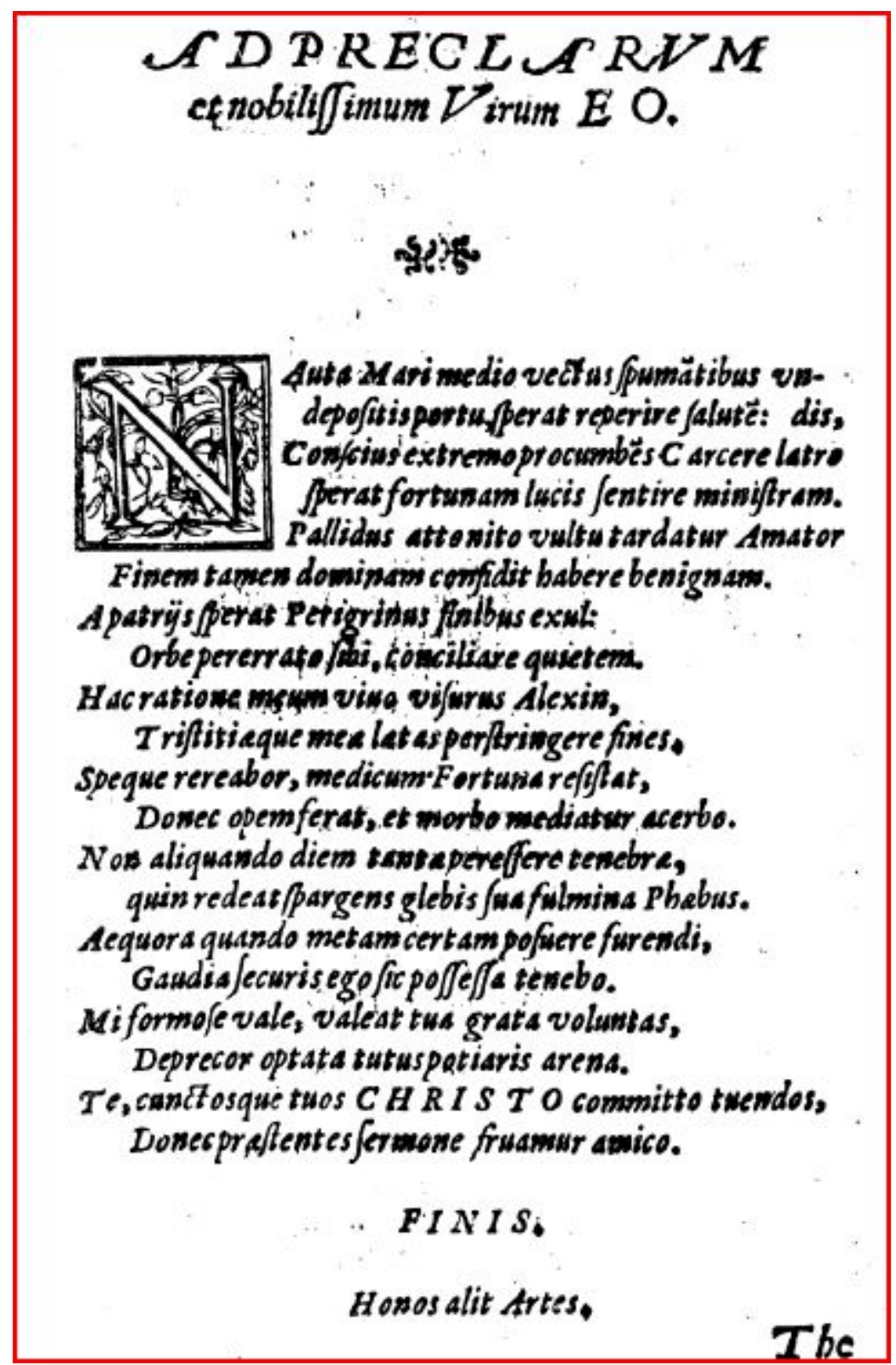

Figure 2. Latin poetic dedication “Virum E O” in Munday’s 1579 Mirrour of Mutabilitie.

If the 1579 Latin poem had not been followed by Munday’s later often-adopted motto, "Honos Alit Artes" (Honor nourishes the arts), there might be debate about who was the real author of that poem, since Munday rarely if ever wrote in Latin. By contrast, Oxford contributed a sophisticated Latin dedication to Bartholomew Clerke's 1571/2 De Curiali (The Courtier) Latin translation from Baldassar Castiglione's 1528 Cortegiano Italian original, alongside a dedication by Clerke's patron Thomas Sackville, Lord Buckhurst and later Earl of Dorset (Nelson, 2003, p. 237). And in 1578, writing in Latin, Gabriel Harvey had praised Oxford's Latin works as “more polished” than those of Castiglione, and among “your many Latin things” (Nelson, 2003, p. 2), now lost. So, did Oxford write that 1579 Latin poem to describe his own sea voyage musings? I think Oxford was more likely the Latinist than that Munday was—but since this is a side issue for this article, we'll let Munday have the 
credit and press on, except to note that pseudonymous, anonymous, and other deliberately misdirected works (e.g., using initials or even whole names of others, possibly without their knowledge) were not rare in the “Golden Age of English Literature," with Munday in particular associated with more than his share of pseudonyms. $^{3}$

Similarly, in the front matter of Robert Greene’s 1584 Gvvydonius The carde of fancie was a dedication in English prose to Oxford (see Figures 3 and 4), but shortly below it was a dedicatory poem in Latin (see Figure 5) in which Greene-or a mysterious, possibly-pseudonym "Richard Portington”- used wordplay on the Latin word "VERE", which alone or as a form of "verum" meant "to be true, truthfulness, fair, or fact” (see Figures 6 and 7; possibly it is the root for our "verify"). ${ }^{4}$ Whoever was the actual author of the poem, it was obviously inspired by or a tribute to Oxford's surname “de Vere”, which itself meant essentially “of Truth”. This article suggests that, as with Munday’s 1579 English poems, Greene-Portington’s 1584 Latin poem and its deft wordplay may be an acrostic, although in this case the acrostic was in Latin, was less obvious, and its meaning was blurred by the difficulties of translating Latin both generally and in this specific case. Earlier scholars haven't recognized the acrostic (we will see that at least one expert denies it's existence), and in fact Greene's Latin poem has itself been only rarely discussed by scholars until recently. Seeing that there was no known poet with the name "Portington” or "Portingtonus" ("Richard” or not), and Green rarely wrote in Latin, again as with Munday’s Latin poem, we may suspect an arrogant nobleman such as Oxford of having written the 1584 Latin poem to riff on his own name.

\footnotetext{
${ }^{3}$ Per the Short Title Catalogue (STC), Munday pseudonyms included "Shepherd Tonie”, "Lazarus Pyot”, "Simon Smell-knave”, and others. Nelson (2003, pp. 236-239) listed a number of the literati, in addition to Munday and Greene, who dedicated works to Oxford. Also, in the pages 226-28 and 287-92 Nelson discussed “Oxford’s Literary Circle”, listing Thomas Watson, George Peele, Thomas Nash, and even George Buck (or Buc, after 1608 "Master of the Revels" with censorship control over plays and playhouses), among others. So, it’s notable that a number in "Oxford's Circle” particularly Munday, Greene, Lyly, and Nash, were involved in the 1588-92 "Marprelate Controversy," hired by the Episcopacy to use pseudonyms in writing pamphlets to defend the Anglican prelates against "Martinist" Puritan attackers (pages 226-228 show that Oxford himself was a victim of attacks by Puritan Gabriel Harvey, and strongly defended by Lyly and Nash). For more on "Oxford's Circle” and the Marprelate controversy, see Appleton, Elizabeth (1985), Edward de Vere and the War of Words, Toronto, ON, Elizabethan Press.
}

4 "Whitaker's Words" (source of Figure 6) is handy and accurate enough, but as will be discussed in this article, users not being careful can be misled by it, as by any dictionary, when alternate definitions or context-dependent connotations are in play. Traupman (1966, p. 440) defined "vere" (from a guide p. 4, both vowels are pronounced like the vowel in "pet") as an adverb meaning "really, truly." Simpson (1968, pp. xiii, 636) had the two vowels as "long” and defined "vere" as an adverb "from verus; q.v." which pointed to page 638, "verus -a -um, adj.” meaning "true, real, genuine," "truthful” or "reasonable” in other contexts. Traupman also has "verum" as a noun meaning "the truth, reality" or "what is right, duty."

Still, I was puzzled by Whitaker's definition of "vere", where in some contexts it can mean Spring or Youth in addition to the Traupman definition. So, I sent questions to a Latinist friend in England, who requests to remain anonymous, and he sent me the message in Figure 7 by e-mail, which derives from Lewis and Short's massive and definitive Latin-English dictionary. There you'll see it resembles Whitaker's definition in many ways, because of "vere" forms for "ver" and other Latin words aside from "verus". In particular, the various uses of "vere” in connection with Spring, as in "vere prius flores" or "vere novo", reinforces what were in Whitaker, particular his “spring; spring time of life, youth”.

Note that my English friend's note (see Figure 7) began with the fact that "vere means a 'boar' in old French", which I had discovered in my own French dictionaries, but wasn't sure was relevant to this discussion. Still, it shows why the Earls of Oxford adopted the boar as their symbol, part of their heraldic symbology. And it may throw doubt on the legend that the boar was adopted by them from the purported death of the 9th Earl of Oxford after being gored to death by a boar while hunting in France. 


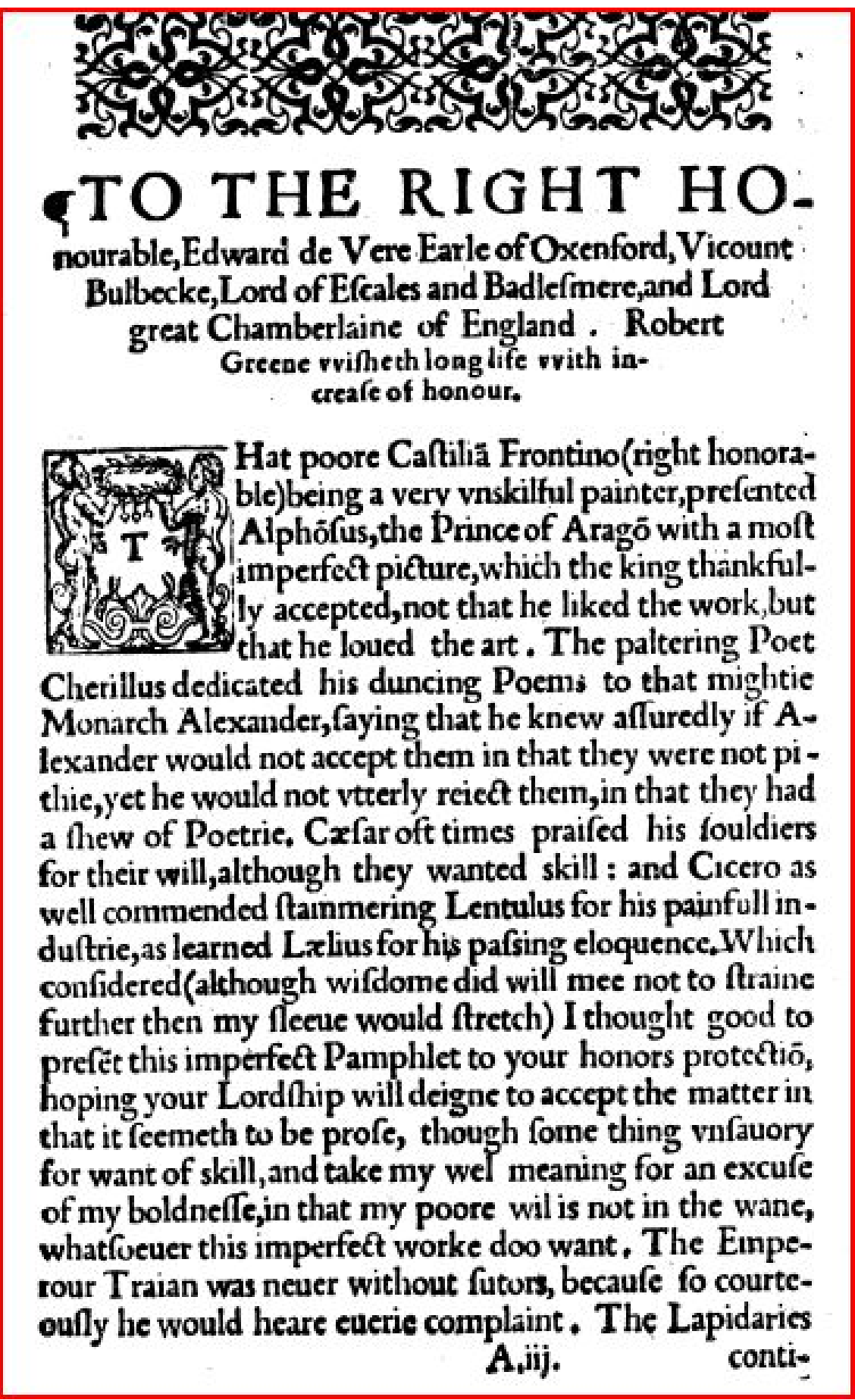

Figure 3. English prose dedication in Robert Greene’s 1584 Gvvyndonius, first page. 


\section{The Epifle Dedicatorie.}

continually frequented the Court of Adobrandinus, be: caufe it was his chiefe ftudie to fearch out the nature of ftones. All that courted to Atlanta were hunters, and none fued to Sapho but Poets. Wherefoeuer Mxcanas lodgeth, thether no doubt will fchollers flocke. And your honour being a worthie fauourer and fofterer of learning, hath forced many through your exquifite vertue, to offer the firlt fruits of their ftudie at the lhrine of your Lordhips curtefie. But though they haue waded farre $\&$ found mines,and I gadded abroad to get nothing but Mites,yet - this I affure my felfe, that they neuer prefented vnto your Honour their treafure with a more willing minde, then I doo this fimple tra?h, which I hope your Lordihip will fo accept. Refting therefore vpon your honours wonted clemencie, I commit your Lordhip to the Almightie.

Your Lordhips moft dutifully to commannd;

\section{Robert Greene,}

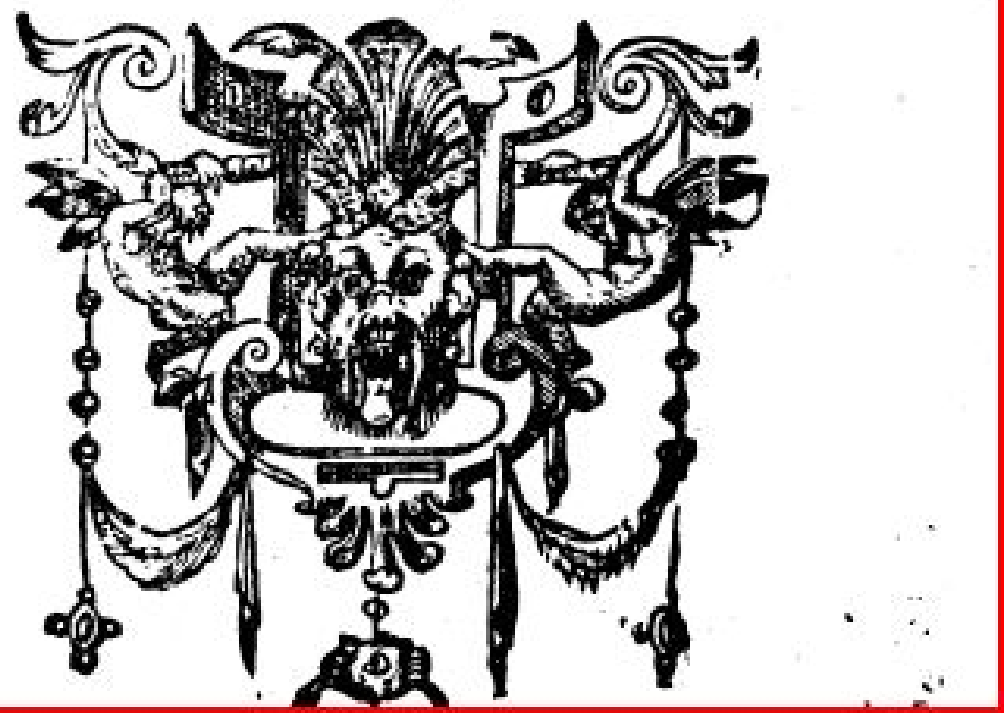

Figure 4. English prose dedication in Robert Greene’s 1584 Gvvyndonius, second page. 


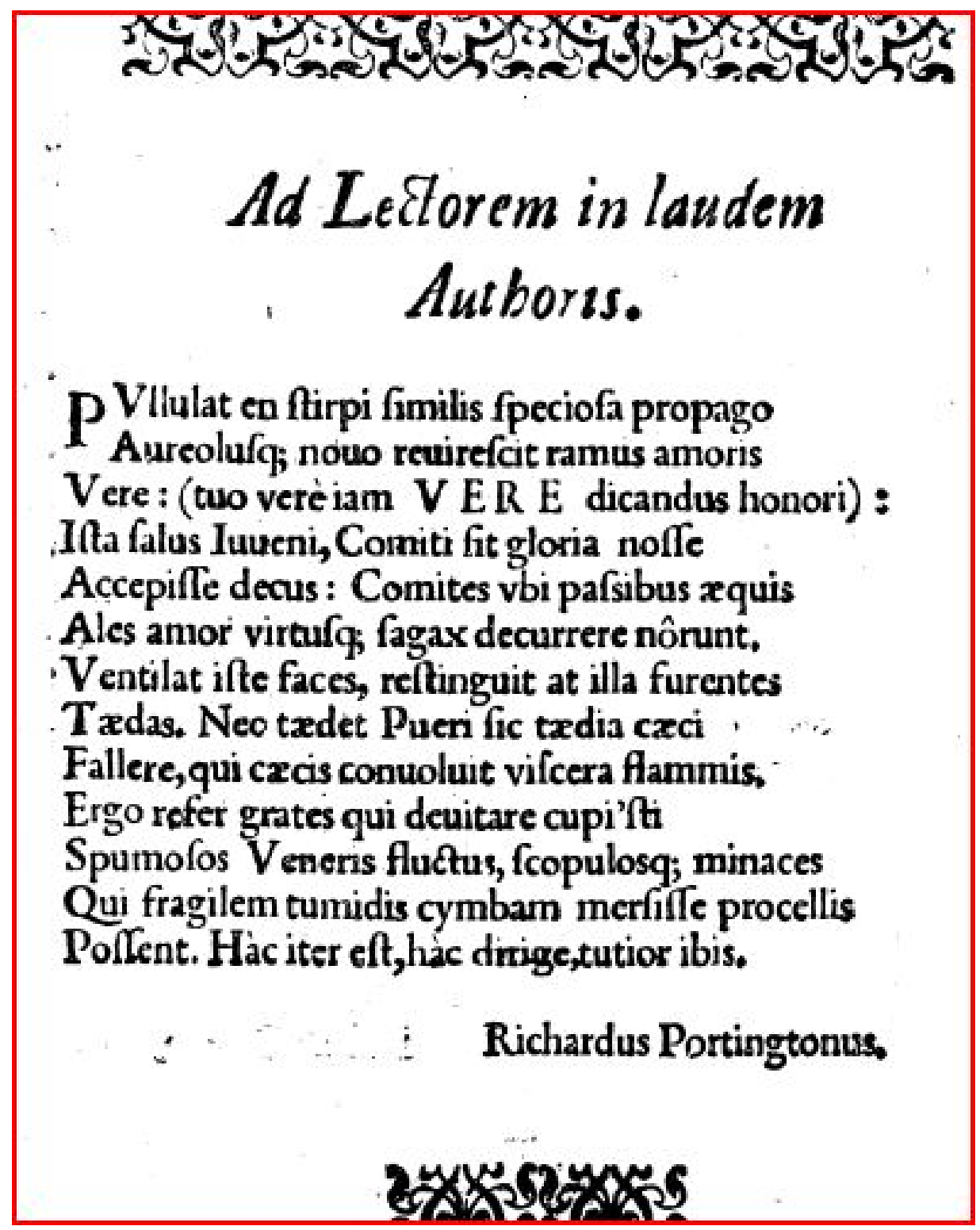

Figure 5. Latin poetic dedication to "V E R E” in Greene’s 1584 Gvvyndonius. 


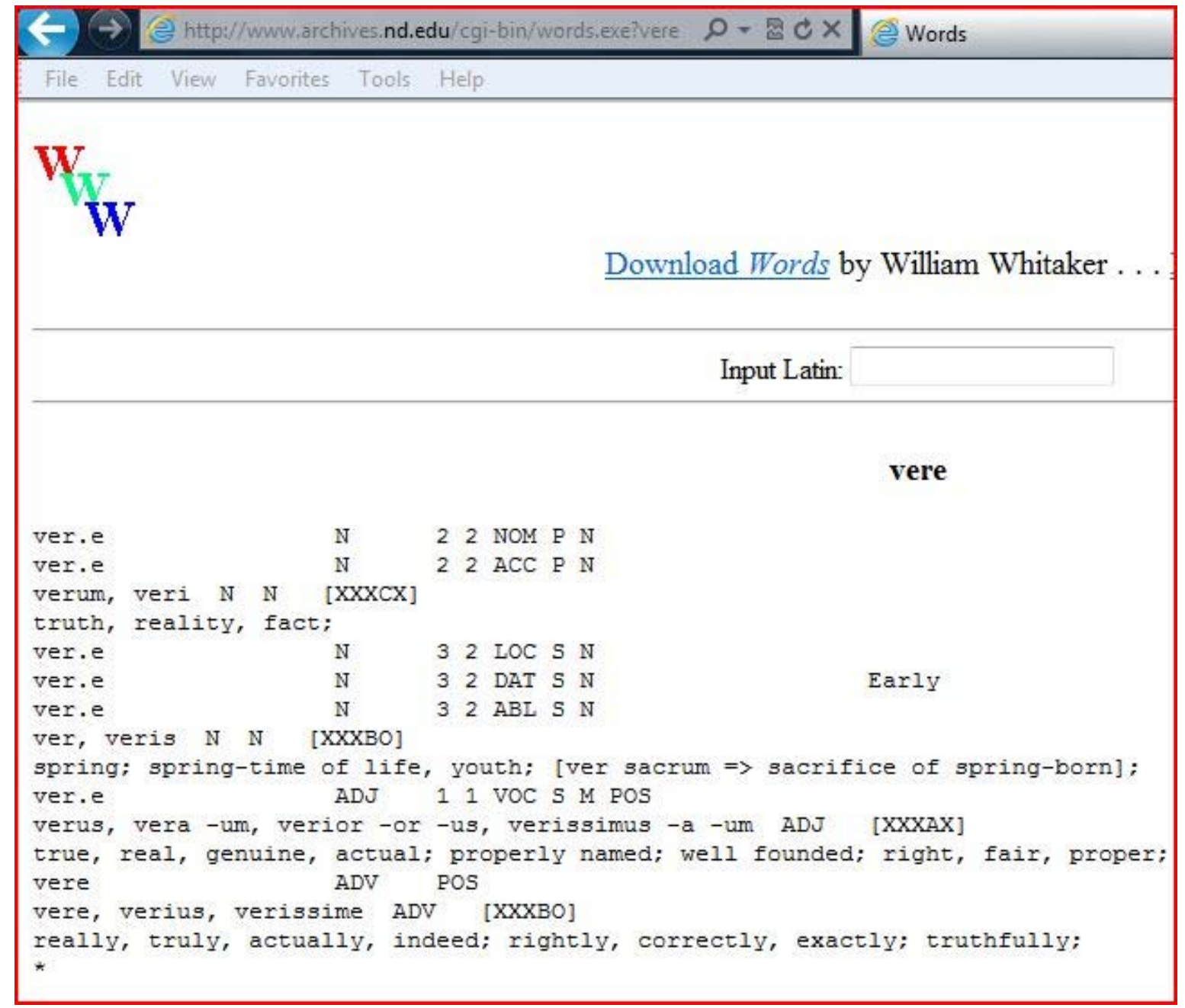

Figure 6. "Whitaker's Words” elaborate definition of "Vere”. 
Vere means a 'boar' in old French and in Latin means 'truly' (from verus 'true'); ver (without the second e) is Latin for the Spring and in poetic idiom can be used to mean 'youth'. Lewis and Short is the definitive Latin dictionary:

vērē , according to truth, truly, really, in fact; properly, rightly, aright:

"hoc quom fit, ibi non vere vivitur," Ter. Heaut. 1, 1, 102 Fleck:

"honestum, quod proprie vereque dicitur, id in sapientibus est solis," Cic. Off. 3, 3, 13:

"quis putare vere potest, etc.," id. Rep. 1, 17, 28: "vereducere," id. ib. 1, 38, 60:

"verene hoc memoriae proditum est? etc.," id. $i b$. 2, 15, 28:

"immo, si vere volumus dicere, jam incohavit bellum." Liv. 41, 23, 13:

"omnia vere vates locuta est," Verg. A. 6, 188: "vere an dolo," Spart. Sev. 5.Comp.:

"libentius quam verius," Cic. Mil. 29, 78: "Ligures latronesverius quam justi hostes," Liv. 40, 27, 10.Sup.: "verissime loquor," Cic. Att. 5, 21, 7: "verissime dicere," id. Rep. 2, 4, 8.

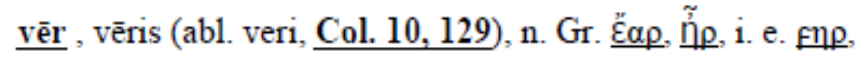

I.the spring.

I. Lit., Varr. L. L. 6, § 9 Müll.; id. R. R. 1, 28, 1; Plaut. Truc. 2, 4, 2; Lucr. 5, 737; Cic. Verr. 2, 5, 10, § 27; id. Lael. 19, 70: "vere novo," Verg. G. 1, 43; Hor. C. 1, 4, 1; 4, 7, 9; 4, 12, 1: "primo vere," at the beginning of spring, Cato, R. R. 50; Hor. C. 3, 7, 2.-Prov.:

"vere prius flores, aestu numerabis aristas," Ov. Tr. 4, 1, 57.-

II. Transf., the productions of spring: "cum breve Cecropiae ver populantur apes," Mart. 9, 14, 2. - So esp. freq., ver sacrum, a special offering presented from the firstlings of spring, which it was customary to vow in critical circumstances:

"ver sacrum vovendi mos fuit Italis. Magnis enim periculis adductivovebant, quaecumque proximo vere $\underline{\mathrm{n}}$ ata essent apud se animalia immolaturos, etc.," Fest. p. 379 Müll.; cf. id. s. v. Mamertini, p. 158; id. s. v Sacrani, p. 321; Sisenn. ap. Non. 522, 17: "ver sacrum vovendum, si bellatum prospere esset, etc." Liv. $\underline{22,9,10}$; cf. "the votive formula," id. 22, 10, ; so id. $33,44,1 ; \underline{34,44,1}$ sqq. Weissenb. ad loc.; Just. 24, 4,1.-

II. Trop., the spring-time of life, youth (poet.): "jucundum cum aetas florida ver ageret," Cat. 68,16 ; $\underline{\text { Ov. }}$ M. 10.85.

Figure 7. Definitions for "Vere” from Lewis \& Short.

If the acrostic I suggest for the 1584 Latin poem is valid, it hints at the dilemma of an Elizabethan court poet, such as Oxford was, having to choose between court or public venues, but not both—i.e., to avoid the "stigma of print". That "stigma”, or 16th century concept so named in modern times to describe it, derived originally from Castiglione's 1528 Cortegiano, which outlined the good attributes to help a successful courtier stand out from his many competitors for favor at court, including dancing, singing, writing verses, and many more serious traits (see Opdyke (1903), front-matter, for a summary of his English translation of Cortegiano) ${ }^{5}$. However, the courtier was warned against taking his "idlenesses" too seriously, because sycophants could take advantage of their pride. It was unseemly for an English nobleman to publish his own verses during his lifetime-far better to circulate his works among his friends and relatives, and if those works were meritorious they would be published posthumously by admirers. Such was the case of Oxford's uncle the Earl of Surrey (executed 1547, 1st published 1567); by Oxford's rival at court, Sir Philip Sidney (died in battle 1586, 1st published 1590); by Sir Robert

${ }^{5}$ See also https://en.wikipedia.org/wiki/Stigma_of_print. 
Sidney (later Earl of Leicester, died 1626, his voluminous MS books of poetry 1st published 1984); and others. Still, adherence to the "stigma” was spotty, such as Sir Philip Sidney's friend and biographer, Sir Fulke Greville (later Lord Brooke) who to his great protest found that several of his plays were stolen and published by "pirates" before his 1628 death, but otherwise left a great body of works, including plays and sonnets, to be published posthumously. Still, Prof. Steven May's 1980 article overreached by claiming that the "stigma of print" was “mythical”, and Prof. J. W. Saunders' 1951 article’s account of the "stigma” was more realistic. As Hess (2012, pp. 17-20) argued there were social penalties to be paid for violators, such as when the Marquess of Winchester stopped having any votes for the Garter Knighthood after his "Idlenesses" were published in 1586 \& 87. That may have happened to Oxford as well, since votes for his Garter similarly declined, with some fluxuation, after the publication of most of his extant poetry in 1576 (Nelson, 2003, pp. 172 for 1576, 179, 233, \& 269 for 1581). Moreover, Oxford and Sackville were two examples of another kind of "victim" of the "stigma of print". Each had most of their extant poetry published while they were at college or in their early 20s, and though each continued to be celebrated for their poetry, little new poetry attributed to them ever appeared-perhaps like Sir Robert Sidney, it was all in MS and never got published — or perhaps that was the way Oxford and Sackville actually wanted it. A noble family was shamed as a whole, not just the individual suffered. Members of Oxford's family held the powerful post of Lord Chamberlain from 1603 to 1641, with powerful influence over the publishing industry, capable of either suppressing publication of Oxford's works due to family wishes, or possibly continuing Oxford's own wishes for suppression. ${ }^{6}$

Since both the 1579 and 1584 Latin poems were dedicated to Oxford, both poets' use of acrostics and double-entendre may show that Oxford enjoyed such "simple puzzles" with fairly obscure meanings and half-hidden stories; and both may help inform Greene's and Oxford's view of the stigma of print. But most importantly, both show that Oxford enjoyed witty Latin poetry!

One goal in this article is to examine and discuss the difficulty of translating Latin or Latinate poetry, especially when there are obscure subtexts at play, and to show that even the best translators can have subjective opinions which inhibit their full appreciation of the text. For this, each of the two poems is accorded a separate discussion involving multiple translations. Because this author's suspicions, theories, inquiries, and too-literal translations help inform the final conclusions, these are touched on in notes for each poem, but admittedly they are not the most accurate or best translations. To compensate, this author has made the acquaintance of Dr. Dana F. Sutton, a dedicated Stratfordian (i.e., Orthodox scholar) who is a Professor Emeritus in Latin at the University of California, Irvine, and who has created a valuable research tool dedicated to exploring Elizabethan-Jacobean

\footnotetext{
${ }^{6}$ After 1576 Paradise of Dainty Delights (and newer editions to 1586), several “E.O.” or even "E. of O.” poems occurred in the 1590 "pirated” 1st edition of Sir Philip Sidney’s Astrophel and Stella and one in1593 Phoenix Nest. Parts of the "E.O.” poems from Astrophel were republished as definitely by Oxford in 1600 Englands Parnassus, but May-1991 (pp. 269-86) declined to attribute them to Oxford after all. Oxford's total extant poems attributed by such authors as J. Thomas Looney or Ruth Miller total between 25 to 30, but many of those were signed "Ignoto" (= "Unknown," "Strange," or even "Ignoble”). May dismissed many of those and found a few others that he did assign to Oxford, for a total of about 20. Unfortunately, that left out many of the best. Yet, Hess (2005) argued that Oxford also wrote the 460-line “Another Rare Dreame” (also in 1593 Phoenix Nest and said to be by an unnamed author with M.A.s from both universities - which was a short list including Oxford!). "Dreame" would double the number of high-quality lines attributable to Oxford, thereby enabling a fairer comparison with the larger number of lines of quality verses by other poets (Sidney, Spenser, Daniel, Shakespeare, etc.).
} 
works in Latin, called "The Philological Museum”, many extant today only in manuscript (MS). Via e-mail, Dr. Sutton has provided this author with superior prose translations for each poem, plus valuable side comments and criticism. And these are featured first, alongside of other translations and this author's discussions, for each poem. Rather than trying to provide a "definitive" presentation for each of the two poems, this author provides his own narrative and analysis following that of Dr. Sutton, and then translations by others. Intelligent readers are free to draw their own conclusions, knowing in advance that Dr. Sutton has a vastly superior knowledge of Latin, undoubtedly provides superior translations, but perhaps isn't as aware of wider historical and social contexts as readers of this journal may be.

\section{Munday’s “Virum E O” Dedication to Oxford in 1579 Mirrour of Mutabilitie}

Starting with Anthony Munday’s 1579 Mirrour of Mutabilitie, the first of many books which Munday dedicated to his master the Earl of Oxford, its Latin poem was not acrostic, as were the other dedications to Oxford in Mirrour. The title "Ad Preclarum et nobilissimum Virum E O" reinforces a number of ideas about Oxford-as-Shakespeare that we Oxfordians have long assumed, such as using coded allusions, playing with Oxford's family name "DeVere” (e.g., in the word "Virum”), and toying with Oxford's initials ("E.O.” = Edward Oxenford or Earl of Oxford). These were obviously fair game for poets in Oxford's circle. But when I first found it, my rudimentary Latin skills caused me to hope for more, such as a possible allusion to Pallas Athena, "the Spear-shaker". Alas, the more I've learned about Latin, the less this poem fits my initial hopes. But it is still worth exploring, and provides a nice addition to studying Munday's life and works.

The translation below provided by Dr. Sutton may yield information about Oxford's travels overseas to Italy, and likely briefly to Greece, ${ }^{8}$ in the Summer of 1575 and Oxford's encounter with Dutch pirates upon crossing

\footnotetext{
${ }^{7}$ See from www.philological.bham.ac.uk/.

${ }^{8}$ Although there is some uncertainty about the side-trip to Greece, Oxford wrote to his father-in-law, Lord Burghley on March 17, 1575 (Nelson, 2003, pp. 123-125) as he was preparing to leave Paris for Strasbourg and then Italy. In that letter, aside from acknowledging that his wife was pregnant with his "son" (in July 1575 his daughter Elizabeth was in fact born), and celebrating same, he noted that he was preparing to enter Italy by some other route than via Milan, due to the inquisition then ongoing there (in fact, later reports to Burghley from his banker spies would show that Oxford was in Milan at least twice). He also stated his intent to take up arms against the Turks if the prospect was available (in fact, the Empire and Venice had just negotiated a truce with the Turks, so only Spain under Don Juan of Austria, half-brother of Philip II, was still at war with Constantinople), and to travel as far as Greece and Constantinople. For the latter goals, he noted that he had letters of introduction from King Henri III of France to the Doge of Venice and to the French Ambassador to Constantinople, who was then preparing to depart from Venice. More than that letter, which may have had deliberate deceptions in it, in case of interception, we know that Oxford took with him from Paris to Strasbourg William Lewin, who had been Oxford's wife's tutor, and must have been known to Oxford as one of Burghley's spies. In any case, Lewin took ill and remained in Strasbourg where he continued to send spy reports to Burghley, several times mentioning that Oxford was en route to Greece. Moreover, in Strasbourg, Oxford took into his retinue Nathaniel Baxter, Sir Philip Sidney's tutor in Greek, who accompanied him to Italy (but whose 1606 poem to Oxford's daughter the Countess of Montgomery in Ourania failed to mention any but Italian adventures). Next, a note of Oxford having been sighted in Palermo Sicily, made in Edward Webbe's 1590 Travails, would be consistent with a travel at least briefly to Greece en route to an attempt to encounter Don Juan at either his Sicilian administrative center, or else at his Naples overall headquarters. Subsequent allegations made against Oxford by his enemies in "the 1581 Libels" claimed he had bragged of bribes from and adventures with Don Juan. A 1699 book later contained a skit for a "Palace Masque” that mentions Oxford as part of a group of knights and amazons and may be a record of a masque given at Don Juan's court in Naples (Ibid., p. 140). Then there was a late-September 1575 banker-spy report to Burghley that Oxford had just arrived back in Venice "from Genoa" having hurt his knee "in a Venetian galley” (Ibid., p. 128), which implied that he had sailed along with Don Juan's fleet (much of it Venetian galleys) from Naples to intimidate the "New Nobility" in Genoa, allowing the "Old" to return to power and promptly forgive Philip II his banking debts. In short, the whole business about Greece, the Turks, and Don Juan spell out that Oxford was on a mission, not a mere tourist trip,
} 
the Channel in April 1576 (Munday himself traveled 1578-79 overland only to France and Itlay, not by sea except for the Channel). It may be a lead-in via "my beautiful one” to Lyly's and Munday’s 1579 and 80 stories about "Euphues” (or maybe even to "the fair youth" of the Sonnets?), and via "Phoebus” possibly a prelude to Oxford's role as "the Knight of the Tree of the Sunne" in the January 22, 1580/1 White Hall jousts. Although the poem has beauty, its meaning remains obscure due to oddities of translating Renaissance Latin, Italian, or French to English; it is rife with "double entendre” because of contractions, abbreviations, apparent misspellings, winking idioms, allusions to mythology, etc. So, I wondered if this Munday salutary poem did hide something VEREy special? If Oxford "originated" the works of Shakespeare as early as Eva Turner Clark argued (and as argued in Hess, 2003, pp. 187-308) - i.e., circa 1576 to 1586, with the rest of the story in revisions or revamps, then it would have been natural for Munday to allude to the proto-canon of works in some fashion, even if the "Shake-speare" pseudonym itself yet remained only in private use in 1579. Yet, this poem shows that cryptic allusions to Oxford's genius and contributions to his language were permitted at least as early as 1579, even as his affair with Anne Vavasour was beginning, and the seeds of his later downfall at Court were sowed. If what may be called "the Shakespeare Enterprise" has yielded for us the Bard's canon, Munday may have hinted here at a snapshot of what "the Shakespeare Enterprise” looked like in 1579, only a few years from its origination!

A mystery about Mirrour is how could it have been fashioned entirely by Munday? Though the poems are comparable to others Munday is credited with, it so happens that from Fall 1578 to about July of 1579, Munday was abroad in France and Italy, spying on English expatriates, and revisiting nearly all of the venues that Oxford had seen 1575-76 in Italy. Perhaps he wrote some of the Mirrour poems while traveling, or hastily on his return? But, it seems more likely that he returned to London, resumed his apprenticeship as a printer in the shop of John Allde, and then a poem collection was presented to him for editing, adding to, and publishing under his own name. In other words, this author believes that Munday was often a "publishing front" for others, even for Oxford.

For example, among the four "Bodenham miscellanies" was 1600 \&10 Bel-vedére or the garden of the Muses, where Hess (2003, pp. 425-478) noted that Belvedere (= beautiful to see) is a perfect anagram for $\underline{\text { bel }}$ DeVere (= fair or warlike Oxford)! Munday edited Bel-vedére; but its first edition listed Oxford, Shakespeare, and dozens of other poets. Sadly, unlike 1600 Englands Parnassus and Englands Helicon, Bel-vedére didn’t link verses to names. So, Oxford gets no credit for any Belvedere poems, many of them quite beautiful.

Another puzzle about 1579 Mirrour are the errors or typos in it (some are pointed out below by Dr. Sutton for the Latin poem under discussion). On returning from Italy, did Munday resume his apprenticeship with printer John Allde? Note that about half of Munday's subsequent publications from 1579 to 84 were printed by Allde, so it seems Munday stayed fairly loyal to his master, even as his dedication to Oxford identified his relationship with the Earl as a master-servant one. Thus, it is very likely that Munday helped with setting the type and other chores related to printing Mirrour, and worth pondering whether specific “errors” may have been deliberate. As you read Dr. Sutton's comments, keep that thought in mind.

\section{This Author's Transcription}

Even though an image for each of the two Latin poems will be in the publication of this article, those will

when he went to Italy (see Hess, 2003, pp. 309-397 for a complete rendition of Oxford's overseas missions and the likely whys and wherefores involving the encounter, befuddlement, and eventual destruction of Spain’s great “war-man”, Don Juan). 
lack line \#s, and in any case may be harder to read than these transcriptions. The "nobilissimum Virum E.O." in the title first caught my attention, and then I was struck by line 5's "Pallidus... Amator" (= pallid lover) which I hoped might have double meaning through "Pallidius” allowing "lover or beloved of Pallas" (= the Spear-shaker). That would make sense in this poem's epic context with some similarities to themes from the Odyssey. My transcription is slightly modernized (adding line \#s, end-of-line slashes, f's replaced by s where needed):

Title: Ad Preclarum / et nobilissimum Virum E O.//

1. NAuta Mari medio vectus spuma[n]tibus un-/

2. depositis portu, sperat reperire salute[n]: dis,/

3. Conscius extremo procumbe[n]s Carcere latro/

4. sperat fortunam lucis sentire ministram./

5. Pallidus attonito vultu tardatur Amator/

6. Finem tamen dominam confidit habere benignam./

7. Apatrys sperat Perigrinus finibus exul:/

8. Orbe pererrato sibi, conciliare quietem./

9. Hac ratione meum viuo visurus Alexin,/

10. Tristitiaque mea latas perstringere fines,/

11. Speque rereabor, medicum-Fortuna resistat,/

12. Donec opem ferat, et morbo mediatur acerbo./

13. Non aliquando diem tantaperessere tenebra,/

14. quin redeat spargens glebis sua fulmina Phoebus./

15. Aequor a quando metam certam posuere furendi,/

16. Gaudia securis ego sic possessa tenebo./

17. Mi formose vale, valeat tua grata voluntas,/

18. Deprecor optata tutus potiaris arena./

19. Te, cunctosque tuos CHRISTO committo tuendos,/

20. Donec prastentes sermone fruamur amico./

21. FINIS./

22. Honos alit Artes.

\section{Translation 2013 by Dana F. Sutton, Professor Emeritus of the University of California Ervine:}

[Reconfirmed by Sutton in 2016, line numbers inserted by this author]

1. A sailor, borne on the deep sea after having left the surf behind in the harbor, hopes to regain his safety.

3. A guilt-ridden thief, languishing in his dungeon cell, hopes to experience good fortune as a bringer of light.

5. A pallid lover wears an amazed expression at encountering delay, and yet has confidence that in the end his mistress will be kindly.

7. A foreigner, exiled from his homeland and having wandered the world, hopes to obtain repose.

9. By this same logic, I live in hope of seeing my Alexis and to reach the limit of my sadness.

11. I am refreshed by hope, even if my fortune resists its healer until he brings help and cures my bitter 
disease.

13. Such shadows never oppress the daylight but that Phoebus returns, shedding his beams on the earth.

15. Since the waters have a fixed limit to their rage, so I shall possess joys in secure times.

17. Adieu, my handsome friend, adieu to your goodwill, I pray you gain your hoped-for shore.

19. I commend you and all your friends/companions/kinsmen to Christ's protection until we can meet in person and enjoy friendly conversation.

\section{Comments of Dr. Sutton:}

[e-mail of 12-19-2013, criticizing Munday’s printing]:

"I have problems with this epigram, because it seems to contain several printing errors:

Line 11) rereabor surely should be recreabor,

Line 13) I'm not quite sure what peressere should be. Pressere? (historical perfect of premo),

Lines 15-16) securis might = in securis rebus, as I have translated it here, but it also might be a typo for securus,

Line 19) praestentes is a mistake for praesentes.”

2. [e-mail of 8-28-2016, referring to a question about "Pallidus" (= pallor) as possibly caused by sea-sickness and being very close to "Pallidius" (= lover or beloved of Pallas Athena) given Sutton's criticism of Munday’s printing]:

Line 5) "If you want to say that pallidus has something to [do with] seasickness: we would have pallor caused by seasickness, imprisonment, and unrequited love. I think trying to sneak in a pun on Palladius here is pretty far-fetched. dfs" 


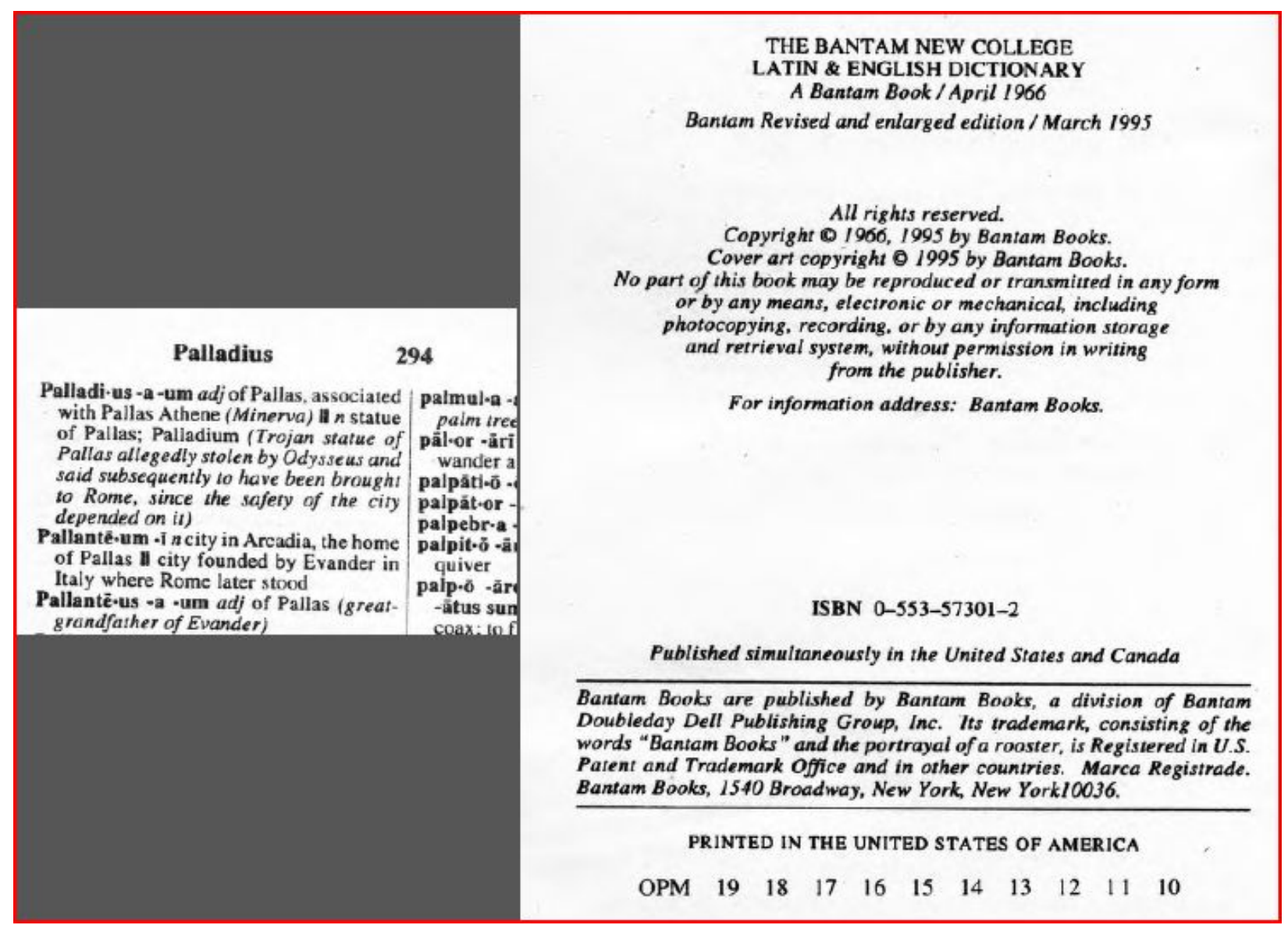

Figure 8. New College Latin \& English Dict., page 294, Definition of "Palladius” = "Pallas”.

[Despite Dr. Sutton's comment, IF it was the intent of Munday, or whoever wrote the poem, to be construed as "Pallidius" (= lover or beloved of Pallas Athena, see Figure 8 for the definition of "Pallidius" from The New College Dictionary, p. 294), Line 5 would read as:

"A lover of Pallas wears an amazed expression at encountering delay, and yet has confidence that in the end his mistress will be kindly."

And that would explain the reference to "his mistress"-none other than the Greek goddess of war, literature, and the arts. Athena (or the Roman Minerva) had an epithet of "the Spear-shaker", from depictions of her brandishing a war spear, beating it between her shield and breastplate, the latter of which bore the "Aegis", or face of the Gorgon, turning men who gazed on it to stone, and screaming forth with a din that would stun enemies into running with fear! So, might it be that an additional error in that poem was that instead of describing a sea-sick voyager, it was actually intended to describe a lover or beloved of the goddess of literature?]

\section{Translation 2009 by an Anonymous Kansas State University Latinist:}

This author's original 2008 translation no longer exists (I used the online translator "Words by William Whitaker” and Traupman, 1995). Fortunately, in 2009 the now-late Prof. Albert W. Burgstahler sought a translation from one of his faculty colleagues, a Stratfordian, who demanded anonymity. The colleague improved upon this author's own poor effort: 
Title: To the famous and most noble man E O.//

1. The sailor in the midst of the sea, borne up by the foaming waves, hopes to heaven to find safety in port,/

3. The conscious thief languishing in prison, aware of the end, hopes to hear fortune bearer of light,/

5. The pale lover, with bewildered countenance, hesitates, yet he has faith that his mistress intends a favorable outcome,/

7. The wanderer exiled from his homeland hopes that he will acquire rest after traveling the world./

9. In this same way I live to see my Alexis [savior?, commander?], and in my sadness I will again think hopefully of approaching the [his?] wide domains./

11. Fortuna resists the doctor until he brings aid and she is cured of sickness by bitterness [i.e., bitter medicine]./

13. Sometimes such darkness would have consumed the daylight, but Phoebus will return scattering his beams upon the earth./

15. When the seas have put a definite end to their raging, I will hold the joys possessed by those who are safe./

17. Farewell, my beautiful one, may your good wishes find success. In safety I pray that you have reached the longed-for shore./

19. I commit you and all your people to the protection of Christ, until we enjoy friendly conversation in each other's presence./

\section{FINIS./}

22. Honor nourishes the arts.

This Author's Discussion: A core of these comments accompanied this author's translation when sent to Dr. Burgstahler and to Dr. Sutton. The anonymous translator agreed that the "E.O." of the title was a double entendre, that the title was a pun of Virum (= virile hero) and Vere (the Earl of Oxford's surname = "Truth"), to whom Munday's book was dedicated. I had hoped some of the following hunches would have merit. But alas, for the most part they remain conjectures or queries. Still, they may be worth some thought:

[Title] Could it also be, "To the famous and most noble hero on proceeding” (i.e., "eo" can = to go, advance, proceed, travel, move along, progress)? Since it was Oxford's oft-used poetry signature (for $\underline{E}$ dward $\underline{O} x e n f o r d$ or

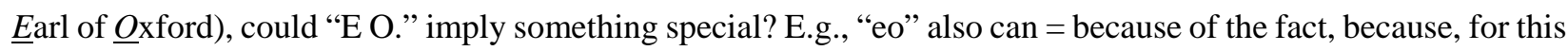
reason. Since the 1579 book was dedicated to Oxford, the translator stated with confidence.

[Ln. 5a] Could "Pallidus... Amator" (= pale lover) obliquely refer to or be conflated with "Pallas" the Spear-shaker, rendering Oxford "the lover of Pallas" (e.g., "Palladine" = of the Spear-shaker, an internationally celebrated knight-errant fable later translated by Munday in his 1588 Palladine of England)? As I read this Munday poem, it's hard to avoid recollection of Homer's Odyssey, in which the hero was guided in a very personal and detailed fashion by Athena, who fought by his side on his return to Ithaca.

[Ln. 5b] Could "dominam" (= lady, mistress) in this context refer not just to the Virgin Mary but also to the virgin "Pallas Athena," the guide and savior of wandering Greek heroes like Odysseus, Jason, and Belerophon?

[Ln. 9] "Alexin" might refer to Alexander the Great, with whom Oxford was compared in several dedications. But in my opinion the best (apparently missed by both translators here) is "Alexis" = "to help, 
defend," even "savior” in Greek and is also a Byzantine military commander title. ${ }^{9}$ Still, it may be that a Greek word/name imbedded in a Latin poem would not have been understood by Latinists, who undoubtedly have large Latin, but "less Greek!”

[Ln. 13] Could "Phoebus" point to Oxford's role-playing, such as to his Summer 1575 trip to and from Italy to the Delphic-Parnassus home of Apollo in Greece? Or possibly it may presage his forthcoming January 22, 1580/1 jousting role as "the Knight of the Tree of the Sunne?"

[Ln. 17] Could "mi formose vale" (literally = my powerfully Beautiful) be equivalent to Greek "Euphues" (= well born, well formed, cultured)? Lyly’s, Munday’s, Greene’s, Lodge’s, and Dickinson’s “euphuistic” works depicted "Euphues" as a cultured knight-errant who adventured from the Muses' Mt. Parnassus in Greece, via Italy, to England on a quest to reform the English language and universities (i.e., roughly Oxford's travels 1575-76). Munday's own 1580 Zelauto dedication would identify “Euphues” as Oxford, addressing by name his overall dedication to Oxford, and then saying, "Given for a freendly entertainment to Euphues, at his late arivall into England."

[Ln. 22] "Honos alit Artes" (= Honor nourishes the Arts) was Munday's often-used motto on his title-pages and dedications from 1579 to1633, many of them dedicated to Oxford, and after 1604 to Oxford's family. So, there’s little doubt this “Virum E O.” poem was meant to be identified as Munday's, whether he actually wrote the poem or not. And in this Munday's first use of it, the motto honored an Earl, rather than to mundanely be just its writer's motto (as in English, in Latin "mundane" = worldly, of the universe, unimaginative, ordinary; and if Munday's name was a pseudonym made up for him, this may be the source of it).

\section{Robert Greene's 1584 Gwydonius, the Carde of Fancie}

In 2009, this author noticed that Robert Greene’s 1584 Gwydonius, the Carde of Fancie had more than just one dedication in it to the 17th Earl of Oxford. The second one is in Latin, allegedly by a possibly pseudonymous "Richard Portington”, and after consulting "Whitaker’s Words” online, I originally believed it was phrased in a way deliberately structured to conflate the names and identities of these three characters:

a) Cupid or a "beloved youth",

b) Oxford, and

c) Greene himself (a belief I no longer can support).

Little interest had been paid to the poem as of 2009, when it was posted it to Hess' website ${ }^{10}$, where it continued to get little attention.

What was striking was the word play touching on Cupid in an epic context with some similarities to themes from the Odyssey. And there was also a possibility that this Latin poem refers to Oxford among multiple "Comites" (plural of Count or Earl) engaged in secret poetry, or using fronts. And it was possible that the Latin poem was an acrostic. But, Latin was full of sly tropes of which this author felt he might have been unaware. So, other translators were.

\footnotetext{
${ }^{9}$ See from https://en.wikipedia.org/wiki/Alexis_(given_name).

10 See Article \# 12 from http://home.earthlink.net/ beornshall/index.html/id25.html.
} 
This Author's Transcription (Bold Highlighting of the Suggested Acrostic):

(Line \#s added; slight modernization of " $\mathrm{f}$ 's" into "s" where needed)

Ad Lectorem in laudem Authoris.

1. PVllulat en stirpi similis speciosa propago /

2. Aureolusq; nouo reuirescit ramus amoris /

3. Vere: (tuo verè iam V E R E dicandus honori): /

4. Ista salus Iuueni, Comiti sit gloria nosse /

5. Accepisse decus: Comites vbi passibus aequis /

6. Ales amor virtusq; fagax decurrere nôrunt. /

7. Ventilat iste faces, restinguit at illa furentes /

8. Taedas. Neo taedet Pueri sic taedia caeci /

9. Fallere, qui caecis conuoluit viscera flammis. /

10. Ergo refer grates qui deuitare cupi'sti /

11. Spumosos Veneris fluc-tus, scopulosq; minaces /

12. Qui fragilem tumidis cymbam mersisse procellis /

13. Possent. Hàc iter est, hàc dirige, tutior ibis. /

Richardus Portingtonus.

Translation of Dana F. Sutton (Prof. Emeritus at Univ. of California Ervine)

[e-mail of 12-19-2013]:

1. See how this handsome scion burgeons like a shoot,

2. and is a golden little branch which revives

3. in the springtime of new love (now it is truly a branch, Vere, to be mentioned to your honor).

4. It should be wholesome for a young man, and

5. glory for an Earl, to have learned and absorbed these things,

6. winged Love (i.e. Cupid) and wise virtue have learned to be your companions,

7. matching your steps. Love fans your fires, whereas virtue quenches those raging fires.

8. Nor is it wearisome thus to cheat the tediums of that blind boy,

9. who envelops our inmost being with his blind fires.

10. Therefore you should give thanks, you who have chosen to avoid

11. the foaming floods of Venus and those threatening reefs

12. which could have the power to sink your fragile barque with raging storms.

13. This is the way, direct yourself along it, and your passage will be safer.

Comments of Dana F. Sutton [in part commenting on this author's translation and inferences]:

1a. [e-mail of 12-19-2013 regarding his translation] "Except that in line 8, I would prefer to read 'Nor is it wearisome to cheat the torches of that blind boy.' Except that taedia ('tediums') is a different word from taeda ('torches'), and the meter of the poem doesn't allow the latter to be substituted for the former. But I can't help wondering if Portington mistakenly confused the two words. The poem contains two puns on Vere's name, Vere (in the springtime) and vere (truly) and a pun on the two meanings of comes, Earl and companion.” 
1b. [Another of 12-19-2013] "Portington is a well-documented name, esp. from Yorkshire. In Foster's Alumni Oxonienses (III.1183 col. 2) there’s a George Portington who took his BA from Oxford in 1581 and a Robert P. who did so in 1580. Both Magdalen College, so probably brothers.”

[[This author was already aware of the Portington debate and replied that instances of George or Robert Portington don't mean that there was a real "Richard Portington", let alone one gifted in Latin poetry, any more than a George or Robert Shakspere meant that there was a real "William Shake-speare!"]]

2. [e-mail of 2-23-2016, referring to a suggested "acrostic," for which see IIIc. below] "I don't buy the idea of the acrostic. Sure, there are some Neo-Latin poems which feature acrostics, but they are a lot more simpleminded than yours. This one strikes me as much too far-fetched. ...[dismissed anti-Stratfordian theories]... Overenthusiastic search for hidden meanings can get one in a lot of trouble. Somebody sufficiently clever and inventive could probably persuade himself he was seeing plenty of acrostic sequences where none can reasonably be thought to exist."

[[From what Dr. Sutton said here and in a later e-mail of 8-28-2016, it may be very unlikely that a valid acrostic existed in this poem. Yet, the presence of "AVT" or "Aut" = "or else" with a credible word before it "Pavia" and another word following, though less credible, seems to build the case for an acrostic with a comparison, Pavia or else FESQP. But Dr. Sutton is probably correct that it's far-fetched, since the FESQP is far from definite, even erroneous.]]

3. [e-mail of 8-28-2016, Responding to a question about whether FESQ could be an abbreviation for “Fescenninus”] "Nobody who knows Latin would abbreviate 'Fescenninus' as Fesq. That would be Fesc. and nothing else. And by the way Pavia doesn't mean 'pastoral' or anything remotely like that. It's the Latin name of Padua. I really don't think there's any hidden acrostic message here. It looks to me like a random bunch of letters, nothing less, nothing more.”

[[This may not refute Dr. Sutton’s opinion of "Pavia”, but Traupman (1995, p. 97) reads "pasto pascere pavi pastus tr to feed; to be food for; to pasture... to use (land) as pasturage..." from which "Pavia” as "land of pavi" was likely related to "pastoral”. But, Dr. Sutton's 8-28 note did confuse two cities-Pavia (just south of Milan) is some 250 miles west of Padua (just southwest of Venice).]]

Hess's 2008 Translation [on which Dr. Sutton was commenting in IIIb.; it retains and emphasizes the first letter of each Latin line]:

To the Reader in praise of the Author. [i.e., somebody, not Greene, who praises Greene!]

1. P Spring forth shoot resembling a splendid offspring/

2. A Of the golden one; fresh strong growing branch of love's/

3. V Youth: (your youth REALLY consecrates honor):/

4. I Of such a prosperous youth, Comrade [or Earl?] is glorious for us to have known/

5. A Grasp glory: Comrades [or Earls?] who keep pace with/

6. A Cupid's virile wings; hasten beeches [i.e., pages?] to be aware/

7. V Brandish your torch of love, quench that rage but be a furious/

8. T Torch. By wearily spinning Boyhood of blind tediousness/

9. F To deceive, that blind person [Death? Cupid?] sweeps away blazing flesh./ 
10. E Thus bring back thanks that shuns lust's style/

11. S Venus’ Foaming wave, [crashing onto?] rocky cliffs; threatening/

12. Q That frail confident small boat [of Charon?] with drowning gale/

13. P. Of power. This journey [to Hades?] exists, this way, pass therein [to oblivion?]./

14. Richard Portington

This author's original comments about the poem's left column as an acrostic (pages cited are from Traupman, 1995):

PAVIA [ = place of pavi $=$ perfect tense of pasco $=$ pastoral $($ or of paveo $=$ quake with fear, panic), or a city in Lombardy, north Italy, on the Po (or Padus) river, source for the name of the city Padua] (pp. 297, 299)

$+\operatorname{AVT}[=$ aut $=\underline{\text { or else }}]($ p. 73$)$

+ FESQ [= abbreviation-contraction for Fescennia, a north Italian city of Tuscany, known for coarse “fescennine verses” in boisterous dramatic dialogue (p. 179)]

+ P. [abbrev. for "Publius” = a name derived from “of the public” (pp. 292, 345), or perhaps the "P.” simply refers to the pseudonym "Portingtonus?”]

Thus, the acrostic alluded to courtier poets' dilemma of choosing between writing:

\section{Pastoral or else coarse verses of the public!}

And, that was a dilemma which Oxford and his poetic circle faced and mastered. Those court poets who dared to publish openly risked “the stigma of print," and there were real penalties for violating that stigma. Hence, most of their works were circulated in manuscript (MS), in private, and much of it is now lost or misattributed.

Recent Update to this author's “Acrostic Theory”:

Recall, the suggested acrostic was PAVIA_AVT_FESQP, for "Pastoral or else...FESQP" with our question being “what was FESQP?” Since Prof. Sutton has deflated "FESQ” = an abbreviation for "fescinine verses," here’s a better idea: “FES. Q. P.,” as in abbreviations of:

-- FES. (“fesceninus” = “of fescinine verses” per Simpson, 1968, p. 245);

-- Q. (“-que” suffix, yielding “fescinusque,” = “fescenine verses and” pp. xiv, 494-495);

-- P. (“proficere” = “to gain profit” p. 800).

This would yield a net translation of "Pastoral or else fescinine verses and to gain profit”, again a statement of the basic dilemma behind a courtier's concern about “the stigma of print”. We'll circulate this idea to see if it "holds water", but until then the acrostic is invalid.

This Author's 2009 Notes: (Following the "Whitaker's Words” online definition of “vere”, three definitions resulted. But other Latin-English dictionaries confirm only that "vere” = "truth")

[line 3] This appears to be a "triple entendre”, as in the above "vere" = "truth" translation, plus two more meanings:

[Truth: (your truth VERE ...)] or [Greene: (your growth GREENE ...)].

Thus, the poem deliberately conflated names and identities of the "beloved youth" of this poem (Cupid + possibly the book's honoree, 34-year old Oxford), with Vere (i.e., Oxford), and with Greene (i.e., the book's putative author). Some have suggested that all three were but one man (credit S. Hughes and N. Green), though I note that with M.A.s at both Oxford and Cambridge, there was little doubt that a real Robert Greene existed, no matter how much he was bowdlerized and fictionalized after his death in Sept. 1592. 
[4] "Comiti" was capitalized, so rather than merely "comrade", the best translation would be "Count" (the companion to a King), and the British equivalent was "Earl”. Because of the reference to "Comites" (also capitalized), it would seem that the main "Earl” was in a body of "Earls", possibly the circle of Oxford's mentor the Earl of Sussex (dead in 1584 but alive in 1580 when Gwydonis was first entered into the S.R.).

[6] To Greco-Romans, the beech (or birch?) was a symbol of wisdom and knowledge, and book pages were made from thin slices of its wood (Grimassi, Raven, The Old Religion of Southern Europe [aka, Ways of the Strega], St. Paul, MN, 2003, Llewellyn Publ., p. 224).

[12] Per the online Latin translator, "cymba, cymbae" = "skiff, small boat; (esp. that in which Charon ferried the dead across the Styx)."

[13] About the last line: in Romano-Egyptian religion, the ibis bird-headed Thoth was the scribe who kept the roll of souls in the underworld — and to strike a name meant that a person never existed (note the use of "est" = is, exists). The gods weighed the soul's heart against a feather of truth, and if the heart weighed more, Thoth would strike the name ${ }^{11}$. Thus, ending the above poem with "ibis" meant the Latin "ibi" for "therein" plus the "ibis" for the bird of "oblivion."

[14] Was "Richard Portington" a pseudonym or front? Might the name have been a sort of portmanteau? The "-char-" of "Richard" may hint at Charon, the ferryman in Hades, or at Charybdis, the whirlpool monster of the Odyssey; "porting” reinforces the ferryman-whirlpool theme; and even the "tonus" residue of Portingtonus means "shade, tension, or clap of thunder", adding to the Hades imagery! Although a Roger Portington was several times an MP from south Yorkshire, and the family was prominent there, no Richard is in the DNB or ODNB. "One hit wonder" poets are often suspicious and no other poetry or other information is known about Richard Portington. I believe here it was a contrived name, or pseudonym, or what I have described elsewhere as "an unwitting front” (i.e., in a remote province, there was no reason that a provincial man with such a name would know that his name was being used to front for literary wags in distant London!).

\section{Translation 2001 by Tom Holland}

From Gwydonius, or the Card of Fancy, edited with introduction and notes by Carmine G. Di Biase, Barnaby Riche Society Publications 13 (Ottawa: Dovehouse Editions, 2001, p. 201), as noted in 2003 by Nina Green $^{12}$. This author concedes this translation is superior to the author's own, but notice the translation of "VERE" as "SPRING" rather than "TRUTH".

To the Reader, in Praise of the Author

1. Behold, a beauteous shoot, resembling its stock, is sprouting, and a gilded branch of love

2. once more grows green in early spring: (now in SPRING it must be truly consecrated to

3. your honor). Let it be the salvation of the young man, and the boast of his companion,

4. that he knew how to receive the glory of that occasion when winged Love and wise Virtue

5. knew how to accompany him as comrades with equal steps. Love fans his torches, but

6. Virtue extinguishes these fires of madness. There is no offence in the deceiving,

7. wearisome behavior of the blind Boy, who wraps hearts in unseen flames of passion.

\footnotetext{
11 See from www.site-ology.com/egypt/RELIG.HTM.

12 See from www.oxford-shakespeare.com/Greene/Gwydonius.pdf.
} 
8. Therefore give thanks, you who wished to avoid the foamy waves and threatening reefs of

9. Venus, which could have sunk your fragile bark in the swelling squalls. This way lies

10. your journey, steer this way and you will travel more safely.

11. Richard Portington.

Translation 2015 of Michael Le Gassick (of England, who died January 12, 2016, taken from his unpublished paper “Gwydonius and Robert Greene”).

Again this author concedes the superiority of this translation to the author's own, but notice he adroitly dodged a core question by simply leaving it as "V E R E" (i.e., Oxford's surname), although at the beginning of line 3 he translated "vere" into "Spring".

TO THE READER IN praise of the Author.

1. Behold from the stock a similar handsome shoot is sprouting

2. And the gilded branch of love grows green anew

3. In Spring: (to thee truly now V E R E is to be dedicated to thine honour):

4. To the Youth that vigour, to the Fellow-traveller the renown he were to have known

5. The glory to have received: where by equal steps

6. Hastening winged love and perceptive virtue will have recognised the Fellow-travellers,

7. The one fans the flames, but the other quenches the raging

8. Torches. Nor is he weary of the Boy thus to deceive the weariness of the invisible man,

9. Who folds the entrails into invisible flames,

10. Therefore restore the thanks thou hast longed for and avoid

11. The foaming waves and jutting rocky crags of Venus

12. Which could have overturned a fragile small boat in the violent tempests.

13. In this way is the path, in this way direct thyself, thou wilt proceed more safely.

14. Richard Portington

\section{Analysis and Conclusion}

Readers can see that this author's discussions with Dr. Sutton and the anonymous Latinist friend of the late Dr. Burgstahler at Kansas State University have at times been politely skeptical. Yet, Sutton's translations are the most accurate, and his opinions on other matters need to be strongly considered and taken into account. Still, other opinions may have merit.

To the point, the discussion of whether an acrostic exists in Greene's 1584 Latin poem isn't merely a matter of opinion. Normally acrostics are self-validating, very simple "codes” which follow reasonable rules, and their existence or validity becomes self evident; so, one might argue that lack of agreement about this author's acrostic discovery in the Greene-Portington Latin poem is a strong reason to suspect it is a mirage rather than a real acrostic. Yet, the "reasonable rules" can be subjective, and under the rules of Latin usage, abbreviations and contractions are common. Thus, we find in the first letters of each line the likely unambiguous Latin words "Pavia Avt" (= "Pastoral or else”) followed by FES (probably = an abbreviation for "coarse fescennine verses", unless a more sensible solution is found) followed by an admittedly ambiguous "Q. P.” So, what does "Q. P.” abbreviate? That's why this author's modified theory given in IIIc. above should be examined (yielding "Pastoral or else 
fescennine verses and to profit"). In English, the nature of a deliberately enigmatic poem is "to keep 'em guessing," often by an unfinished sentence or abbreviated word(s), and the same can be true in Latin. An open-ended puzzle doesn't necessarily negate the existence of a code or an acrostic, unless no reasonable solutions can be suggested. Yet, Dr. Sutton's warning is valid - that acrostics, though common enough, can likely be found anywhere one wishes to find them. But I feel that would be true only if one wishes to stretch the rules enough!

For an English-language example of "stretching the rules", the alleged English-language "string cipher" acrostic in the poem Escu d'Amour, featured in George Gascoigne's 1573 A Hundred Sundrie Flowres (pp. 343-344; also cited in Ruth L. Miller's 1975 republication on her pp. 31-36), is not a valid acrostic. This is because the solution originally proposed by B. M. Ward in the 1930s asked "decoders" to make too many guesses, take one letter from certain lines, several from others, skip lines irregularly, use a different pattern going down the right margin than was used for going up the left margin, etc. ${ }^{13}$ Hence, Ward's solution is a phantasm of its discoverer's imagination-as this 1584 Latin acrostic seems to be according to Sutton! Sutton knows Latin poetry far better than this author does, but he may not know Greene, Munday, or Oxford's circle as well as present readers do. Thus, readers should judge for themselves about this suggested acrostic, about its implication for understanding Oxford's circle.

We've just explored a few of the many ways in which any "Latinate” work (in Latin, Italian, Spanish, French, etc.) can be very difficult to translate into English, even by expert Latinists like Dr. Sutton and the other translators above (not counting this author, who denies being a Latinist). Definitions, dialects, idioms, misprints, and a host of other things differed from location to location, even within a given language (especially in Italy, where each city had its own dialect). To illustrate differing idioms with a familiar phrase in English (which language is only about 35\% Latinate, from $25 \%$ French and $10 \%$ Latin), a simple phrase "bless his heart" can appear obvious in many places, but in the southeastern U.S., it likely means more like "what a clown that guy is!" And we who speak English don't have to put up with all the Latinate abbreviations and truncations (although, Twitterisms and modern jargon might be emerging complications). From someone who has studied four Latinate languages and mastered none, this author attests that problems with regular and irregular verb declensions, grammar, gender identification, and a host of other complexities are abundant in each of them. And yet one of the hardest languages for a foreigner to learn is English, because of all the "rules" we have which are broken as soon as they're pronounced. As can be imagined, this makes translating into English, let alone into or from Latin, a difficult proposition. If we were to have ten Latinist experts translate a few selections of Elizabethan Latin poetry, we'd likely get a dozen or more translations, with meaning left ambiguous in various places (the translations given above are examples, differing from each other in many ways). Such is the penalty of the "Tower of Babel".

Turning to another topic, this author believes Greene's poem has potential bearing on identity of the "beloved youth" of the 1609 Sonnets and 1640 Poems (derived in part from Figure 6, where Whitaker's definition for "vere" possibly includes "youth"). But that requires us to examine a wider context. Just a few weeks after the entry of Gwydonius into the Stationers Registry (S.R.) in April 1584, the June 1584 Pandora, or the Musyke of His Mistresse Diana was published (as dated in the signature of its profuse dedication to Oxford). Pandora was a

${ }^{13}$ As discussed in Hess’ Article \# 13 at http://home.earthlink.net/ beornshall/index.html/id26.html. 
hodge-podge of good and bad poetry, covering a gamut of topics, and borrowing heavily from Greco-Roman imagery. It was also innovative, introducing the ode for the first time in English, and including sonnets purported to have been written by two women—by the Countess of Oxford and by "Her Majesty" (thought by many to have been Q. Elizabeth, I believe it was actually meant to be construed as by Marguerite de Valois, Queen of Navarre)! Yet, within it are allusions to characters and themes very similar to those later used in "Shake-speare's" 1609 Sonnets. And that should not be surprising, since Shakespeare's principle poetic source was Golding's translation of Ovid's Metamorphoses, and it turns out that Pandora cribs generously from the French Pleiades group of poets, particularly from Ronsard, and from Desportes. So, I believe the 1609 Sonnets do likewise emulate from the French (Sir Sidney Lee’s [1898] 1912 Life of Shakespeare [pp. 83-122] and 1905 Sonnets of Shakespeare [pp. 19, 25-26, 28 \& elsewhere referencing specific French poets] each go into some detail about the borrowings from or emulating of French poets in the Sonnets, as was true in other Shakespeare works-a strong argument that the Bard was a prolific reader of French poetry with extraordinary access to said poetry, much of it not translated into English in his lifetime!).

In addition to being dedicated profusely to Oxford, Pandora several times referred to Oxford as "Dever" (= of green or the season Spring). But the putative author of Pandora was "John Soowthern," where I've argued "Soowthern" or "Soothern" is little more than Oxford's surname (DeVere) translated into Middle English for "Of Truth" = "Of Sooth" = "Soothern". ${ }^{14}$ The importance of this is in what immediately followed Pandora's best poetry (several sonnets falsely attributed to Oxford's wife and to "her majesty", where recently scholars have identified that poetry was little more than paraphrase from the French of Philipe Desportes' 1573-83 Diane sonnets (see Moody, 1989 for details)).

At top of the page, after those poems, was more poetry in which Pandora's author brags, "That Soothern which will rayse English to the skies”. By itself, Pandora didn’t support such an elevated brag, unless it had companion pieces, and it may be that Greene was familiar with those now lost pieces. I nominate for one collection of those pieces the 1592 Diana sonnets by "H.C.” (Henry Constable or even Henry Chettle?), which was printed by Pandora's printer (John Charlewood), had considerable dependence on Desportes' Diane, and shared the same focus on "Diana" that Pandora's extended title shows that it did.

The crux of this argument involving Pandora was that in 16th century French poetry (Desportes was the royal Poet Laureate 1575-1603), many allusions were made to Cupid as "the beloved youth". And Greene/Portington's poem seems to uphold just such an interpretation in an Oxford-related context. If Oxford or his circle was indeed the source of Shakespeare’s poetry, then we should note that Sonnets \#s 153 and 154 were merely paraphrases of a circa 500 A.D. paeon to Cupid, "the little love god", by the Byzantine poet Marianus Scholasticus, a part of "The Greek Anthology", which was a massive body of literature inherited by Italian collectors upon the Turks' 1453 sack of Constantinople (see Gillespie, 2004, pp. 204, 320). Objectively, all references to "the Beloved Youth" in Shakespeare's Sonnets can be interpreted satisfactorily as references to Cupid (who in myth traveled into Hades to redeem his beloved "Psyche" [= soul in Latin, as borrowed from the Greek]). It may be argued that actual persons were inspirational "Muses" or "Cupids", although definitive identifications can only be conjectured, which certainly doesn't support any autobiographical theories. As such,

${ }^{14}$ See Hess' discussion from http://home.earthlink.net/ beornshall/index.html/id19.html. 
all arguments that any Elizabethan or Jacobean person was "the Beloved youth" only dance on insupportable clouds, and actually detracts from our basic Shakespearean arguments. Whereas, "the Beloved youth" as Eros-Cupid would have been universally understood by Latin savy readers of English and French poetry in Elizabethan and Jacobean times, and as amply demonstrated in Ovid's Metamorphoses, by the way.

In conclusion to this article, it's fascinating that even in translation, without rhymes, and with various interpretations available, both the Munday and Greene Latin poems were beautiful literature, bravely hinting that they conveyed secret information, but coyly avoiding being specific. The same could be said about the poetry of Nostradamus, or any of the "great poetry" of the Renaissance. Artful ambiguity and hinted-at messages were the heart and soul of poetic enjoyment. And we need to put that out front and center as we consider the "meanings" of each sonnet in the 1609 cycle. Intrinsically, Munday's 1579 artful Latin poem had the feature of being within one errant letter "i” in portraying Oxford's 1575-76 trip as an Odyssey worthy of Homer, complete with weariness and resorting to divine inspiration from Pallas Athena, "his mistress". And Greene’s poem (purportedly written by a "Richard Portington") artfully depicted another Odyssey narrative and succeeded in conflating "the Beloved Youth" (or Eros-Cupid) with Oxford himself. Both poems' beauty go beyond the English poetry of either Munday or Greene, wherein both of them were second-rate English poets. So, it may be that each poet had a collaborator more capable in Latin poetry than the purported authors could show in their English exercises. Or perhaps it was just that Latin itself was truly a superior medium? Either way, through these two poems we have glimpsed Oxford and his honorable literary circle, supplementing what we otherwise knew. As Munday's motto said, "Honor nourishes the Arts", (and it seems that "Honor" is another way of interpreting “deVere”).

\section{References}

Gillespie, S. (2004). Shakespeare's books: A dictionary of Shakespeare's sources. London: Continuum. ISBN \# 0-8264-7775-5.

Hess, W. R. (2003). The dark side of Shakespeare, Vol. II of III: An Elizabethan courtier, diplo-mat, spymaster, \& epic hero. Lincoln, NE: Writers Club Press. ISBN \# 0-595-29390-5.

Hess, W. R. (2005). “Another rare dreame”: Is this an "authentic” Oxford poem?. The Oxfordian, VIII, 3-16. Retrieved from http://shakespeare-oxford.com/wp-content/oxfordian/Hess-Dreame.pdf; improves on Hess’ 2003 website Article \#1 Retrieved from http://home.earthlink.net/ beornshall/index.html/id12.html

Hess, W. R. (March 2012). Did Shakespeare have a literary mentor?. DeVere Soc. News, 16-21.

Lee, S. Sir. (1898/1901). A life of Shakespeare. New York: Macmillan.

Lee, S. Sir. (1905). Sonnets of Shakespeare. Oxford: Clarendon Press.

May, S. W. (1980). Tudor Aristocrats \& the mythical "Stigma of Print". Renaissance Papers. Retrieved from http://shakespeareauthorship.com/stigma.html

May, S. W. (1991). The Elizabethan courtier poets (The poems and their contexts).Columbia, MO: University of Missouri Press.

Miller, R. L., \& Ward, B. M. (1975). A Hundreth Sundrie Flowres, from the original Ed. of 1573. G. Gascoigne, (Ed.). Port Washington, NY: Kennikat Press Corp.

Moody, E. (1989). Six elegiac poems, possibly by Anne Cecil de Vere, Countess of Oxford. English Literary Review, 19, 152-170. Retrieved from http://www.jimandellen.org/anne.cecil.poems.html

Nelson, A. H. (2003). Monstrous adversary: The life of Edward de Vere, 17th Earl of Oxford. Liverpool: Liverpool University Press. ISBN 0-85323-688-7. Retrieved from http://www.isbs.com

Opdyke, L. E. (1903). The book of the courtier by Baldesar Castiglione. New York: Scribner. Retrieved from http://archive.org/stream/bookofcourtier00castuoft/bookofcourtier00castuoft_djvu.txt

Saunders, J. W. (1951). The stigma of print: A note on the social bases of Tudor poetry. Essays in Criticism, I(2), 139-164. Retrieved from http://eic.oxfordjournals.org/content/I/2/139.full.pdf+html

Lewis, C. T., \& Short, C. (Eds.). (1879/1958). New Latin dictionary. Oxford: Clarendon Press.

Simpson, D. P. (1959/1968). Cassell's Latin dictionary. NY: Wiley Publishing. ISBN 0-02522580-4. 
Traupman, J. C. (1966/1995). The New college Latin \& English dictionary. NY: Bantam Books. ISBN 0-553-57301-2; and "Whitaker's Words" (Retrieved from http://www.archives.nd.edu/cgi-bin/words.exe) an online Latin translation tool recommended by the Notre Dame University site (www.archives.nd.edu). See endnote \# 4.

Constable, H. (1592). Diana the praises of his mistres, in certaine sweete sonnets. By H.C. London: John Charlewood for Richard Smith (STC-5637-526:24).

Gascoigne, G. (1573). A Hundreth Sundrie flowres. London: Henrie Bynneman and Henry Middleton for Richarde Smith (STC-11635-244:02).

Greene, R. (1584). Gvvydonius the carde of fancie. London: Thomas East for William Ponsonby (STC-12262-385:06).

Munday, A. (1579). Mirrour of Mutabilitie. London: John Allde for Richard Ballard (STC-18276-549:10). [During 1576-84 Munday was apprenticed to John Allde, except 1578-79 when he traveled to and from Italy. So, Munday likely helped print his own book in late 1579, maybe others later in his career, particularly when associated with printer John Charlewood. Thus, some "typos” in this book may have been deliberate, with Munday setting the type!].

Soowthern, J. (1584). Pandora, the musyque of the beautie, of his mistresse Diana. London: John Charlewood for Thomas Hackette (STC-22928-354:13). See Mark Anderson's website for this author's transcription of Pandora (www.sourcetext.com/sourcebook/index.htm). 